University of Nebraska - Lincoln

DigitalCommons@University of Nebraska - Lincoln

Faculty Publications in the Biological Sciences

Papers in the Biological Sciences

10-1919

New Species of Water Mites of the Genus Arrhenurus

Ruth Marshall

University of Nebraska - Lincoln

Follow this and additional works at: https://digitalcommons.unl.edu/bioscifacpub

Part of the Life Sciences Commons

Marshall, Ruth, "New Species of Water Mites of the Genus Arrhenurus" (1919). Faculty Publications in the Biological Sciences. 26.

https://digitalcommons.unl.edu/bioscifacpub/26

This Article is brought to you for free and open access by the Papers in the Biological Sciences at DigitalCommons@University of Nebraska - Lincoln. It has been accepted for inclusion in Faculty Publications in the Biological Sciences by an authorized administrator of DigitalCommons@University of Nebraska - Lincoln. 


\title{
NEW SPECIES OF WATER MITES OF THE GENUS ARRHENURUS
}

\author{
BY \\ Ruth MARShaLI
}

About ninety genera of Hydrachnidae are now recognized, with some eight hundred species. About one-fourth of these species belong to the single genus Arrhenurus. Fifty-five have been described for North America, chiefly from the upper Mississippi valley. This paper adds one new species.

The hydrachnid fauna of South America has received little attention. Only eleven species have been described, of which five are for the females only. Dr. F. Koenike, in two papers (1894, 1905), published descriptions of two species (A. corniger, A. ludificator) found in material sent to him from Brazil. Dr. C. Ribago (1902) described a single species from Colombia (A.oxyurus). Dr. E. von Daday (1905) described seven new species from material collected in Paraguay; these were designated $A$. anisitsi, A. apertus, A. meridionalis, A. multangulus, A. propinquus, A. uncatus, A. trichoporus. Dr. C. Walter, in a paper published in 1912, described one new species (A. fuhrmanai), from Colombia. The present paper adds six new species.

Material from Asia has been very scanty. Twenty-two species of Arrhenuri have been recorded; of these eight are from Asia Minor, mostly species found also in Europe. The remaining species have been found in the islands of Ceylon, Java and Sumatra. This paper adds two new species from China.

The author has been very fortunate in securing the material for the descriptions of the nine new species of Arrhenuri included in this paper, and thanks are extended to the collectors who generously contributed it. The greater part of the material was found in collections made in northern South America by the late Harriet B. Merrill, in 1908 and 1909, and now in the possession of Dr. E. A. Birge, of the University of Wisconsin, who kindly permitted the author to sort out the water mites. Professor A. S. Pearse, of the 
University of Wisconsin, contributed material from Venezuela. Mr. C. Juday, of the Wisconsin Natural History Survey, gave some material in his possession which had been collected by Professor N. Gist Gee, of Soochaw, China. Dr. R. A. Muttkowski sent material found by him in the lakes at Madison, Wisconsin, and which contained one new Arrhenurus.

Arrhenurus serratus nov. spec.

Pl. XXIX, Figs. 1-7

In form this mite resembles $A$. brachyurus Viets (1914), found in Germany. The latter, however, is shown without a petiole, a conspicuous feature of the new species. The enclosed dorsal area is large and runs over on to the small appendix. The petiole is a long, slim transparent structure with an upward curve in its posterior half where it has a saw-toothed appearance. At its base, on the ventral side of the appendix, there are two saber-like bristles. There is a delicate hyaline appendage and numerous stout hairs on the appendix, with several smaller ones on the rest of the body. The fourth joint of the fourth leg shows a well-developed spur with a few short curved hairs at its end. The body measures $1.0 \mathrm{~mm}$. without the projecting petiole which measures $0.2 \mathrm{~mm}$. The female has a length of $1.3 \mathrm{~mm}$., and is ovate in form. The genital area is large and the wing-shaped areas are broad and extend nearly straight outward from the cleft. The color is olive green in preserved material.

Three males and four females were found in Lake Mendota, at Madison, Wisconsin, June 18, 1915, by Dr. R. A. Muttkowski.

\section{Arrhenurus asiaticus nov. spec.}

Pl. XXIX, Figs. 8-10

In dorsal aspect this species bears a general resemblance to that of the North American species A. montifer Marshall, and shows the characteristics of the subgenus Micrurus in the stout form, small enclosed dorsal area and short scalloped appendix with a medial incision. The petiole is stout and turned abruptly upward and has no hyaline appendage. The fourth leg lacks the spur on the fourth joint, but this and the preceding segment have sharp points on the distal ends. The palpi are stout. The color of the preserved specimin is pale blue green with brown mottles. The body length is $0.9 \mathrm{~mm}$. 
The single male on which this description is based was found by Mr. N. Gist Gee, of the University of Soochaw, China, in material taken from canals and small lakes in the region.

\section{Arrhenurus distinctus nov. spec.}

Pl. XXX, Figs. 14-16

This form resembles $A$. orientalis Daday (1898), found in Ceylon. The large and well-developed petiole has a similar form in the two species, but in the related form it is more flaring at the end and relatively larger. The new species has a longer body, the entire length, including the petiole being $1.10 \mathrm{~mm}$., the petiole alone being $0.75 \mathrm{~mm}$. long. No trace of a hyaline appendage was found. There is a well-developed spur on the fourth leg. The palpi are stout. The stout body with the well-developed appendix having conspicuous lateral projections directed outward, and the pair of sickle-shaped projections within the dorsal enclosed area place the new species in a well-defined group of the subgenus Arrhenurus noted by the author in a former paper (1908). The color is a pale brown green.

A single male of this species was found with the preceding species in the material from Soochaw, China.

Arrhenurus valencius nov. spec.

Pl. XXIX, Figs. 11-13

A single female from Lake Valencia, Venezuela (July 18, 1918), sent to the author by Professor A. S. Pearse for identification proved to be a new form and its description is now given. It resembles A. multangulus Daday fem. from Paraguay, but is larger $(1.53 \mathrm{~mm}$.). The large conical elevations on the dorsal side of the body which are so conspicuous in both species do not have the same arrangement. In the new species there are four large humps at the posterior end of the body, while the anterior ones and those within the enclosed dorsal area are small. The genital region is small and the wingshaped areas bend abruptly outward. The color of the specimen is blue green.

\section{Arrhenurus merrilli nov. spec.}

Pl. XXX, Figs. 17-18

This species and the four which follow belong to the Merrill collection. It is noteworthy that these five new species as well as most of the other described South American Arrhenuri for which the 
males are known belong to the "long tailed" group, the subgenus Megalurus.

A. merrilli is a small water mite, its total length being only 0.80 $\mathrm{mm}$. It resembles the North American species A. manubriator Marshall. The elevations on the body and appendix are only moderately developed. The epimera end in blunt points. The line enclosing the dorsal area runs over to the ventral side where it closes at the narrow genital wings. There is a small spur on the fourth segment of the fourth leg and segments two and three end in sharp points. The color of the specimen is brownish green.

One male was found by Miss Merrill in a small clay puddle near Marajo, Brazil, May 5, 1908.

\section{Arrhenurus triconicus nov. spec.}

Pl. XXX, Figs. 19-24

Abundant material was found for the study of this species. It resembles $A$. ludificator Koenike and $A$. uncatus Daday; these three species, together with the following species and its related form, are all characterized by the possession of a large conical elevation in the middle of a long slim appendix, a feature which so far has been found in only two others, the North American species $A$. petiolatus Piersig and $A$. cornicularis Marshall. A. triconicus has also two small but well-developed outstanding humps near the end of the appendix. The line enclosing the dorsal area runs ventrally below the small genital wings. The epimeral groups are close together; the first and second develop horn-like projections as in the next species. The entire length of the animal is $0.70 \mathrm{~mm}$. The palpi are characterized by an unusual development of the fourth segment.

The female of this species was identified. The body is obovate and measures $0.50 \mathrm{~mm}$. The epimera show the same tendency to develop horns as in the male. The color is blue green.

Seventeen males and twenty females were found in Miss Merrill's collections. These were taken in May, 1908, at Calama, Rio Maderia, and Marajo, Brazil; and in March, 1909, from canals near Christ's Church, Georgetown, British Guiana.

\section{Arrhenurus epimerosus nov. spec.}

Pl. XXXI, Figs. 25-28

As noted in the preceding description, this species belongs to a small and sharply defined gourp of the subgenus characteirzed by 
the development of a large conical hump near the base of the appendix; like $A$. triconicus it also shows an unusual development of hornlike extensions on the first two pairs of epimera, very striking in this species in the case of the second pair. The latter feature, together with the general form of the appendix, relates this species closely to $A$. corniger Koenike. Fortunately the author is in possession of a specimen which Dr. Koenike had kindly sent of his species and a careful comparison of the two forms was possible. The new species is smaller, measuring only $0.65 \mathrm{~mm}$.; the appendix is slimmer and its conical hump is larger and more anteriorally placed than in the related form. The color is blue green.

Two males were found in Miss Merrill's collections from Brazil (Calama and Marajo, Lake Aray) in 1908.

\section{Arrhenurus maderius nov. spec.}

Pl. XXXI, Figs. 29-32

The formation of humps on the body and appendix is characteristic of several of the described species of South American Arrhenuri. In this and the following species it is the body rather than the appendix which has them. Herfe our large lateral elevations, two dorsal and two posterior, besides two smaller ones by the eyes, give the body an angular form. The dorsal enclosed area is without them; its enclosing line runs ventrally over to the small genital wings. The appendix is broad, scarcely as long as the body proper, and ends in a scolloped border. (In one individual the end is more truncated and the rounded corners more pronounced than is shown in Fig. 29.) Near the end is a small but distinct peg-like petiole (P, Figs. 29, 30), similar to one sometimes found in other males of the subgenus. The palpi have a scanty patch of short fine hairs on the second segment. There is a small spur on the fourth joint of the fourth leg. The length of the entire body is $1.15 \mathrm{~mm}$. The color is brown green in preservation.

Two males of this species occur in collections made by Miss Merrill in 1908, one from Rio Maderia, Brazil, the other from British Guiana.

\section{Arrhenurus quadricornicus nov. spec.}

Pl. XXXI, Figs. 33-37

This is a very striking form, characterized by the enormous development of horns on the body in both sexes. In the male there 
are four large curved ones, two anterior ones on the protuberances over the eyes, and two lateral ones on elongated elevations. The appendix is small at the base, increasing in width and thickness toward the end, and free from conspicuous elevations. The fourth segment of the fourth leg has a moderately long spur with a bunch of long curved hairs. The entire length of the body, including the anterior horns, is $1.30 \mathrm{~mm}$.

In the female, besides the four horns, smaller but similarily placed, there are two larger ones on the posterior corners of the body and four small rounded humps, two within the enclosed dorsal area and two at the extreme end. The palpi are somewhat unusual in form; the second is very broad and bears a small patch of fine hairs on the inner surface. The entire length of the body, including the horns, is $0.90 \mathrm{~mm}$. The color is dark brownish green in preservation.

One male and one female were found in Miss Merrill's collections from Georgetown, British Guinana (canals near Christ's Church), March, 1909.

Lane Technical School, Chicago.

September 1, 1919. 


\section{EXPLANATION OF THE PLATES}

\section{PLATE XXIX}

1. Arrhenurus serratus, dorsal view.

2. Arrhenurus serratus, ventral view of the appendix.

3. Arrhenurus serratus, lateral view.

4. Arrhenurus serratus, left fourth leg, last three segments.

5. Arrhenurus serratus, palpus.

6. Arrhenurus serratus female, dorsal view.

7. Arrhenurus serratus female, epimera.

8. Arrhenurus asiaticus, dorsal view.

9. Arrhenurus asiaticus, ventral view of the end of the appendix.

10. Arrhenurus asiaticus, lateral view.

11. Arrhenurus valencius female, dorsal view.

12. Arrhenurus valencius female, ventral view of the posterior end.

13. Arrhenurus valencius female, palpus.

\section{PLATE XXX}

14. Arrhenurus distinctus, dorsal view.

15. Arrhenurus distinctus, ventral view of the appendix.

16. Arrhenurus distinctus, lateral view.

17. Arrhenurus merrilli, dorsal view.

18. Arrhenurus merrilli, lateral view.

19. Arrhenurus triconicus, dorsal view.

20. Arrhenurus triconicus, lateral view.

21. Arrhenurus triconicus, ventral view of the body.

22. Arrhenurus triconicus, left palpus.

23. Arrhenurus triconicus female, dorsal view.

24. Arrhenurus triconicus female, epimera.

\section{PLATE XXXI}

25. Arrhenurus epimerosus, dorsal view.

26. Arrhenurus epimerosus, lateral view.

27. Arrhenurus epimerosus, ventral view of the body.

28. Arrhenurus epimerosus, left palpus.

29. Arrhenurus maderius, dorsal view; $P$, petiole.

30. Arrhenurus maderius, lateral view; $\mathrm{P}$, petiole.

31. Arrhenurus maderius, ventral view of the genital area and appendix.

32. Arrhenurus maderius, right palpus.

33. Arrhenurus quadricornicus, dorsal view.

34. Arrhenurus quadricornicus, lateral view.

35. Arrhenurus quadricornicus female, dorsal view.

36. Arrhenurus duadricornicus female, ventral view.

37. Arrhenurus quadricornicus female, right palpus. 
TRANSACTIONS OF THE AMERICAN MICROSCOPICAL SOCIETY, VOL. XXXVIII

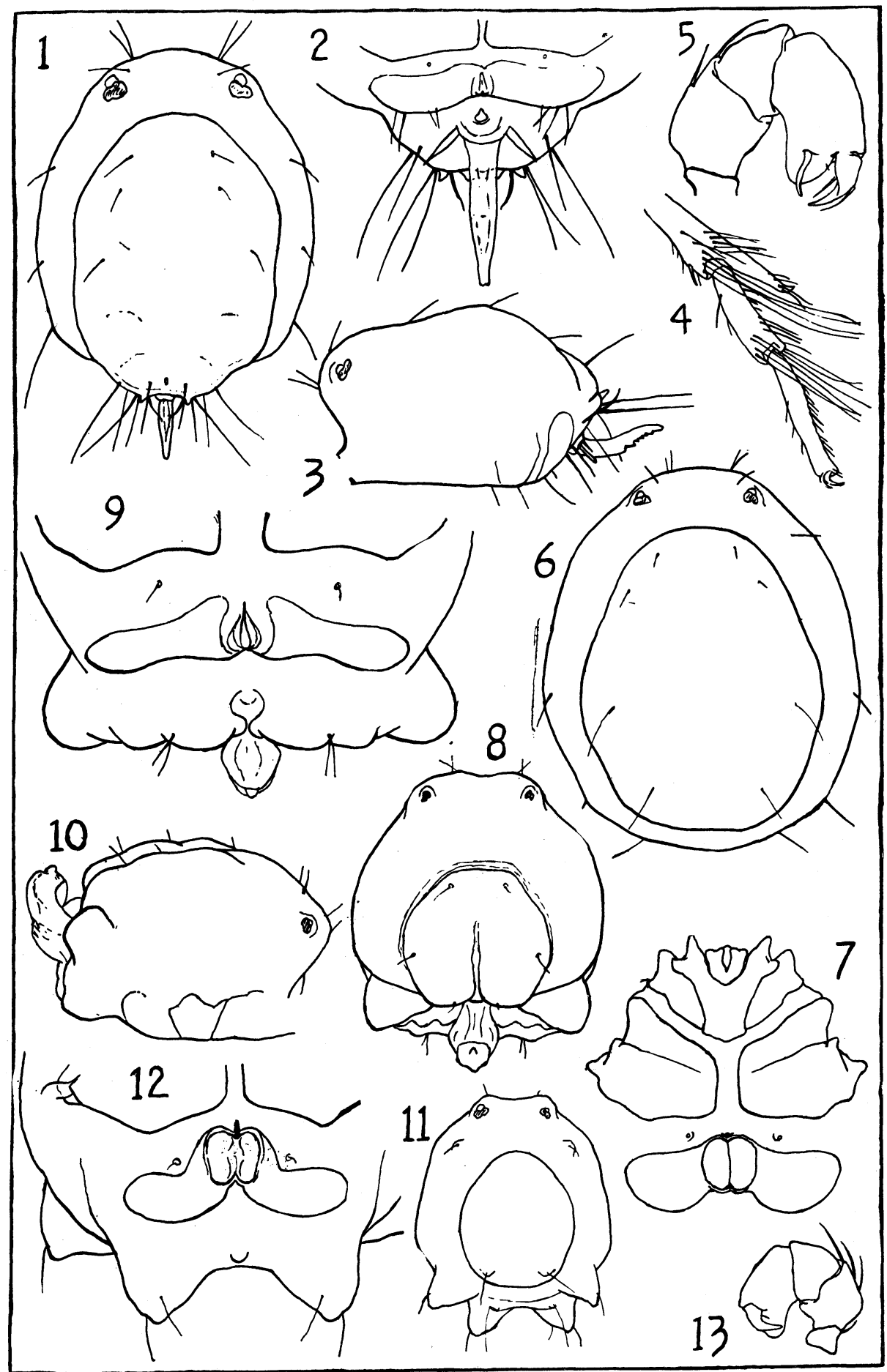


TRANSACTIONS OF THE AMERICAN MICROSCOPICAL SOCIETY, VOL. XXXVIII

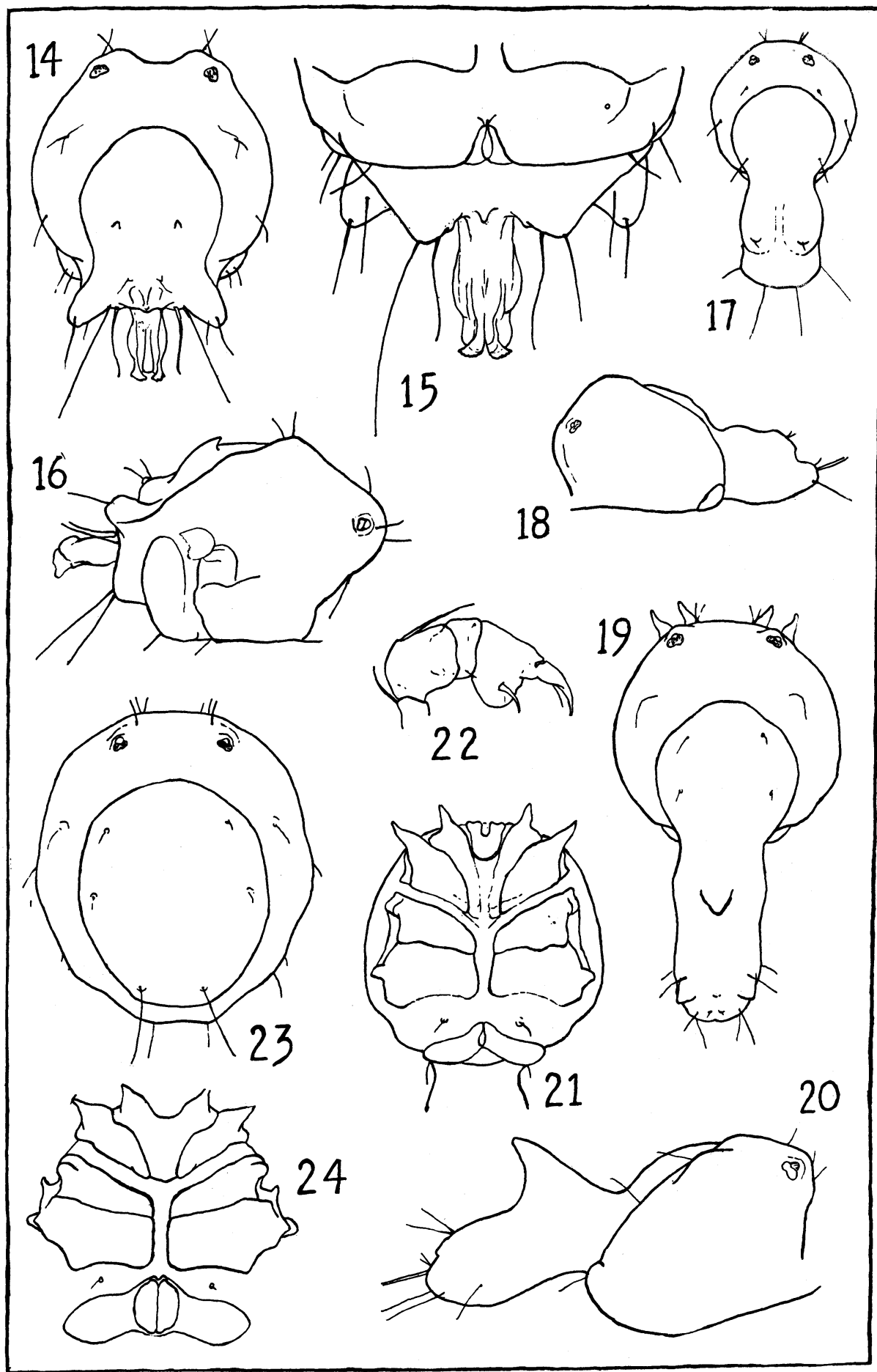

PLATE XXX

MARSHALL 
TRANSACTIONS OF THE AMERICAN MICROSCOPICAL SOCIETY, VOL. XXXVIII

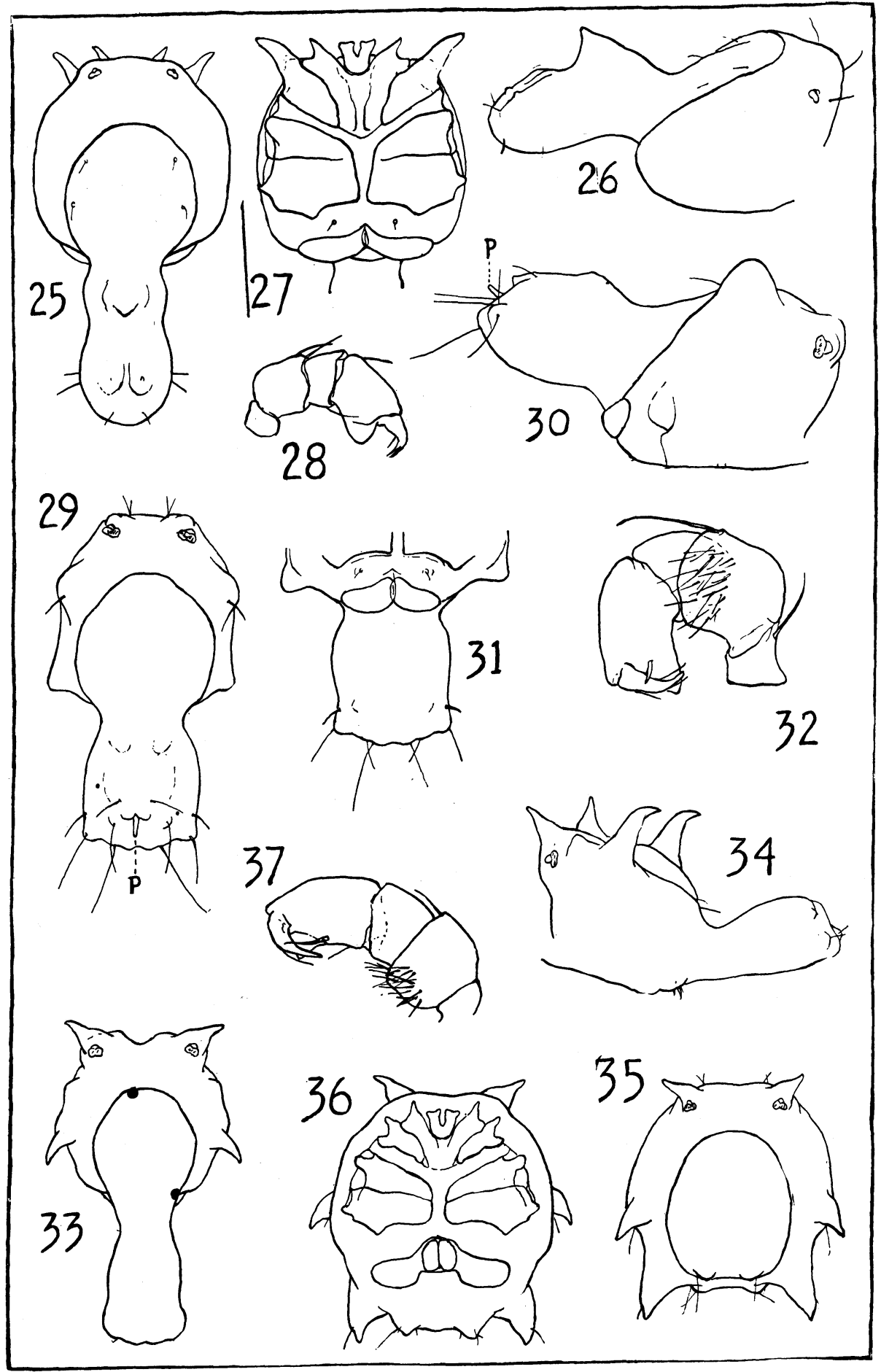

PLATE XXXI

MARSHALL 